\title{
Discrimination of Production Environments of Specialty Coffees by Means of Stable Isotopes and Discriminant Model
}

\author{
Juliana Barbosa ${ }^{1}$, Flavio Borem ${ }^{2}$, Helena Alves ${ }^{2}$, Marcelo Cirillo ${ }^{3}$, Marcia Sartori ${ }^{4} \&$ Carlos Ducatti $^{4}$ \\ ${ }^{1}$ Department of Biology, University of Lavras, Minas Gerais, Brazil \\ 2 Department of Engineering, University of Lavras, Minas Gerais, Brazil \\ ${ }^{3}$ Department of Exact Science, University of Lavras, Minas Gerais, Brazil \\ ${ }^{4}$ Institute of Biosciences, Center for Stable Isotope, University Estadual Paulista, São Paulo, Brazil \\ Correspondence: Juliana Barbosa, Department of Biology, University of Lavras, Minas Gerais, Brazil. Tel: \\ 55-31-7555-7969. E-mail: juliananevesbarbosa@gmail.com
}

\author{
Received: February 8, 2014 Accepted: March 18, 2014 Online Published: April 15, 2014 \\ doi:10.5539/jas.v6n5p55 URL: http://dx.doi.org/10.5539/jas.v6n5p55
}

\begin{abstract}
The south of Minas Gerais, Brazil stands out among various regions through its capacity for production of specialty coffees. Its potential, manifested through being one of the most award-winning Brazilian regions in recent years, has been recognized by the Cup of Excellence (COE). With the evident relationship between product quality and the environment in mind, the need arises for scientific studies to provide a foundation for discrimination of product origin, creating new methods for combating possible fraud. The aim of this study was to evaluate the use of carbon and nitrogen isotopes in discrimination of production environments of specialty coffees from the Serra da Mantiqueira of Minas Gerais by means of the discriminant model. Coffee samples were composed of ripe yellow and red fruits collected manually at altitudes below 1,000 m, from 1,000 to 1,200 m and above $1,200 \mathrm{~m}$. The yellow and red fruits were subjected to dry processing and wet processing, with five replications. A total of 119 samples were used for discrimination of specialty coffee production environments by means of stable isotopes and statistical modeling. The model generated had an accuracy rate of $89 \%$ in discrimination of environments and was composed of the isotope variables of $\delta^{15} \mathrm{~N}, \delta^{13} \mathrm{C}, \% \mathrm{C}, \% \mathrm{~N}, \delta \mathrm{D}, \delta^{18} \mathrm{O}$ (meteoric water) and sensory analysis scores. In addition, for the first time, discrimination of environments on a local geographic scale, within a single municipality, was proposed and successfully concluded. This shows that isotope analysis is an effective method in verifying geographic origin for specialty coffees.
\end{abstract}

Keywords: geographic originality, specialty coffees, altitude, isotopes

\section{Introduction}

Coffee is a popular product that moves the world economy. Ever more demanding domestic and international markets have awakened the interest of large producer countries in respect to indication of geographic origin to add value to the product. The singular characteristics of Brazilian specialty coffees have gained increasing recognition on the international market and are currently classified among the best coffees in the world (COE, 2012). Studies have been developed for the purpose of preserving and ensuring greater security in regard to the authenticity of high prestige products of plant origin, such as wine and coffee, among others. Concentrations of "tracer" elements in coffee depend, among other factors, on geographic origin (Rodrigues et al., 2009). Elements are absorbed by plants with the same isotope proportions as their occurrence in soils and rainfall (Martinelli et al., 2009; RODRIGUES et al., 2011). Therefore, isotopic composition is an excellent indicator of origin or of tracers in the biosphere (Almeida \& Vasconcelos, 2001). Elemental isotopic composition of a plant tissue or organ varies according to its geographic origin (Martinelli et al., 2009; Gonzalvez et al., 2009). In this context, many authors have used different isotopes, correlating them with environmental aspects, in an attempt to obtain an isotopic signature for the most diverse production origins of coffees on a more global scale (Serra et al., 2005; Martinelli et al., 2009; Rodrigues et al., 2009; Rodrigues et al., 2011; Weckerle et al., 2002). Thus, understanding the processes that affect the elemental isotopic composition of coffee beansis fundamental. Fractionation of $\delta^{13} \mathrm{C}$ occurs during the process of photosynthesis and of breathing. The isotopes $\delta \mathrm{D}$ and $\delta^{18} \mathrm{O}$ are strongly subject to the effect of the meteoric water cycle. During the evaporation and condensation phases, they are affected by temperature and 
likewise by latitude. Upon drawing nearer the poles, the $\delta \mathrm{D}$ and $\delta^{18} \mathrm{O}$ abundance in meteoric water becomes less plentiful (Martinelli et al., 2009; Gat, 1996). In regard to the isotopic composition of nitrogen, fractionation results from the interaction of nitrogen fixing plants and from agricultural practices developed in production regions (Gonzalvez et al., 2009). Few studies have made reference to isotope fractionation in seeds. However, no study discusses the relations of isotopic fractionation with the coffee quality. Nevertheless, it is known that all the compounds derived from plant metabolic processes are divided up and redistributed to organs in development, which are known as "sinks". Such studies are important for a better understanding of how this isotopic fractionation occurs, altering or forming the elemental composition of isotopes in coffee beans. These studies are associated with the factors of climate and the physical medium, and a more refined interpretation of this methodology will allow discrimination of production environments of specialty coffees.

In spite of the potential of this methodology for distinguishing coffees originating from different regions on a continental scale, its applicability to a smaller geographic region and its relation to quality have not yet been tested. In this context, the aim of this study was to evaluate the use of $\delta^{15} \mathrm{~N}$ and $\delta^{13} \mathrm{C}$ stable isotopes and carbon/nitrogen percentages and sensory scores in combination with a discriminant model of microenvironments of a single Brazilian coffee production region, allowing identification of its terroirs.

\section{Method}

\subsection{Samples and the Climate}

The coffee beans under study originate from the municipality of Carmo de Minas, which is within the region of the Serra da Mantiqueira of Minas Gerais, which is the second geographic indication for coffee in Brazil. According to the Cup of Excellence, this region has gained worldwide recognition as a producer of high quality coffees (OIC, 2009), which explains the choice of this region as the location to develop this study. The area under study is delimited by the geographic coordinates $22^{\circ} 07^{\prime} 21^{\prime \prime}$ Latitude South and $45^{\circ} 07^{\prime} 45^{\prime \prime}$ Longitude West (IBGE, 2009). The altitude ranges from a minimum of $864 \mathrm{~m}$ to a maximum of $1,634 \mathrm{~m}$. Mean annual temperature is $19.1^{\circ} \mathrm{C}$ and mean annual rainfall is $1568 \mathrm{~mm}$ (IBGE, 2009).

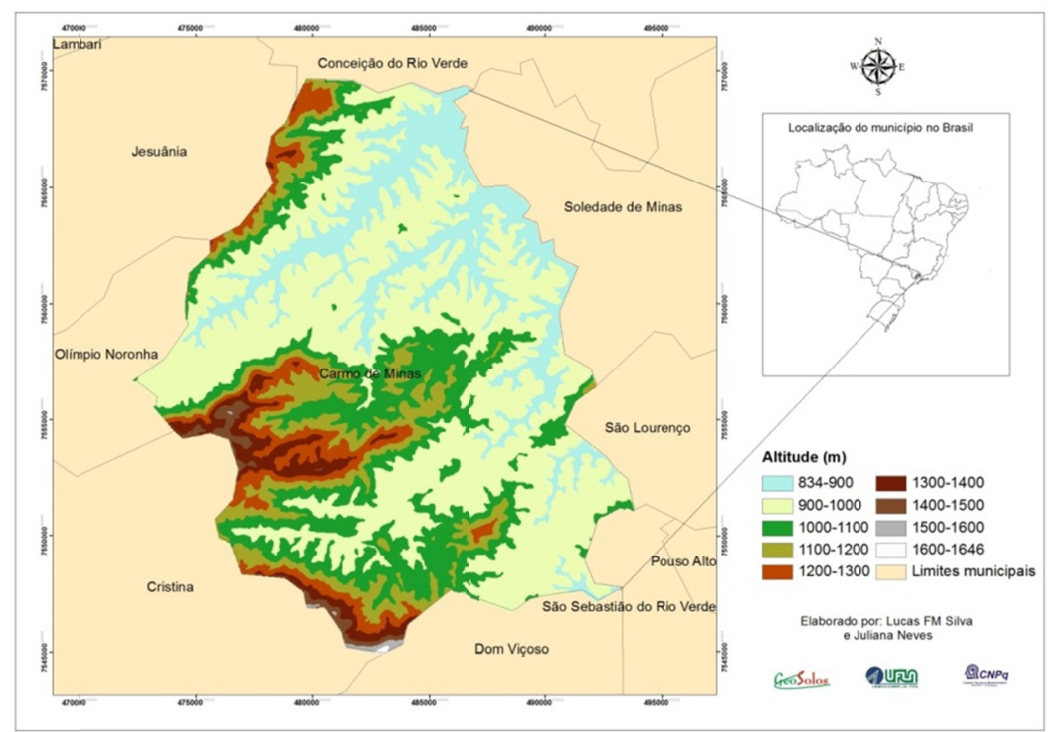

Figure 1. Map of sampling area - Region of the second geographic indication of coffee in Brazil

\subsection{Experimental Design and Quality Control}

Experimental design considered natural processing and hulled/mucilage removed processing, red and yellow fruit color, and the three ranges of altitude of below $1000 \mathrm{~m}, 1000$ to $1200 \mathrm{~m}$ and above $1200 \mathrm{~m}$. To ensure the reliability of the samples, each representative lot contained 5 biological replications. The samples came from the 2009/2010 crop season. All the samples were georeferenced(latitude, longitude and altitude) and collected manually in the ripe cherry stage, and duly processed and selected, maintaining the highest quality beans for the purpose of verifying the true effect of the environment. 


\subsection{Quality Control of the Analyses}

\subsubsection{Sensory}

Sensory analyses were performed only by certified specialty coffee judges, using the methodology proposed by the Specialty Coffee Association of America (SCAA) (Lingle, 2001). The sensory analysis protocol of the SCAA was used for roasting the coffee, whose coloring must correspond to 58 points on the Agtron scale for the whole bean and 63 points for the ground bean, with tolerance of \pm 1 point. In each evaluation, five cups of coffee were cupped, representative of the interactions between genotype and environment, performing a session of sensory analysis for each replication, for a total of five replications. Each type of processing was evaluated separately. For this study, only the final score of the attributes was considered.

\subsubsection{Isotope Ratio Mass Spectrometry-IRMS}

The green coffee beans were ground in a Retsch mill for 5 minutes. This process was performed three times to achieve a particle size of less than $1 \mathrm{~mm}$. After grinding, the samples were dried for 12 hours at $60^{\circ} \mathrm{C}$ and placed in tin capsules, folded and weighed again. The weight of the folded capsule was recorded and used to calculate $\mathrm{C}$ and $\mathrm{N}$ percentage. Elemental analysis was performed in triplicate and the mean and standard deviation was calculated. The certified reference material (CRM) for validation of the method was Wheat Flour Standard OAS. The values for deuterium and oxygen $\left(\delta \mathrm{D}\right.$ and $\left.\delta^{18} \mathrm{O}\right)$ were obtained by calculating the attributes of altitude, longitude and latitude of each sample (into: www.wateriso.eas.purdue.edu).

\subsubsection{Isotope ratio Mass Spectrometry - Combustion Mode (EA-C)}

The stable isotopes of carbon and nitrogen were determined by an Isoprime mass spectrometer. The isotope ratio mass spectrometer was coupled to a Euro EA elemental analyzer. The isotope proportion of the samples was adjusted to international standards (IAEA CH6 and IAEA CH7 for isotope ratio of carbon and IAEA N1 for isotope ratio of nitrogen). The efficiency of the method was verified by means of insertion of laboratory standards among the samples to check stability and to allow correction of "drift" when necessary. Precision was $0.06 \%$ for determination of the carbon isotope ratio and $0.08 \%$ for the nitrogen isotope ratio.

\subsection{Data Statistics}

Models were established by Fisher discriminant analysis, mentioned by Johnson e Wichern (2007) for discrimination of sampled geographic locations. The discriminant function is responsible for explaining the differences among the classification variables (altitude, processing and color). Classification determines the functions of the variables observed, which allows new objects to be classified in one of the "g" populations. The models created follow proposed sampling design. The predictive factors tested in all the models were: the final sensory analysis score of the coffee samples, delta nitrogen $\left(\delta^{15} \mathrm{~N}\right)$, carbon $\left(\delta^{13} \mathrm{C}\right)$, oxygen $\left(\delta^{18} \mathrm{O}\right)$, and deuterium $(\delta \mathrm{D})$, and percentages of carbon $(\% \mathrm{C})$ and nitrogen $(\% \mathrm{~N})$.

\subsubsection{Classification of the Models}

After obtaining discriminant models for their validation a frequency table was obtained as shown in Table 1 in which each cell represented the total number of observations classified within the following situations: $\mathrm{n}_{(1,1)}$ equal to the number of observations belonging to $\pi_{1}$ which were classified in $\pi 1 ; n_{(1,2)}$ equal to the number of observations belonging to $\pi_{1}$ which were classified in $\pi 2 ; \mathrm{n}_{(2,1)}$ equal to the number of observations belonging to $\pi_{2}$ which were classified in $\pi 1$ and, finally, $\mathrm{n}_{(2,2)}$ represented the number of observations belonging to $\pi_{2}$ which were classified in $\pi_{2}$.

Table 1. Summary of the multivariate observations classified according to the linear discriminant model

\begin{tabular}{llll}
\hline & \multicolumn{3}{l}{ Predicted classification } \\
\hline \multirow{3}{*}{ True Classification } & \multicolumn{2}{l}{$\pi_{1}$} & $\pi_{2}$ \\
\cline { 2 - 4 } & $\pi_{1}$ & $\mathrm{n}_{(1,1)}$ & $\mathrm{n}_{(1,2)}$ \\
& $\pi_{2}$ & $\mathrm{n}_{(2,1)}$ & $\mathrm{n}_{(2,2)}$ \\
\hline Total & \multicolumn{2}{c}{$\mathrm{N}=$ total number of observations } \\
\hline
\end{tabular}

From the results obtained by means of construction of Table 1, it was possible to compute the accuracy rate, which was used to evaluate the quality of classification resulting from Fisher's discriminant linear function. Thus, this rate was obtained according to Equation 1: 


$$
\mathrm{T}=\frac{\mathrm{n}_{(1,1)}+\mathrm{n}_{(2,2)}}{\mathrm{N}}
$$

In working with situations that involved more than two classification variables, as is the case of classification by ranges of altitude, a similar procedure was adopted, making due adaptations in discriminant analysis so that the Fisher's discriminant function and the estimate of the cutoff point were adapted to three classifications.

\section{Results and Discussion}

Three classifying models were tested, designated as model 1(for the processing discriminant variable), model 2 (for the color discriminant variable) and model 3 (for the altitude discriminant variable).

\subsection{Model 1}

The model generated by means of the linear response method was able to classify 72 of the 119 samples studied, an accuracy rate of $60 \%$. Nevertheless, few studies relate the manner of processing coffee to isotopic abundance of the elements. The relations between the classification variables and the FITS (FITS reclassifies the data through the ratio between the sum of squares within and between the groups) are represented in Figure 2.

A)

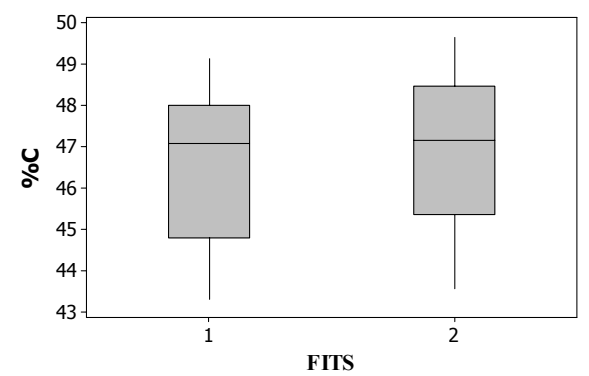

C)

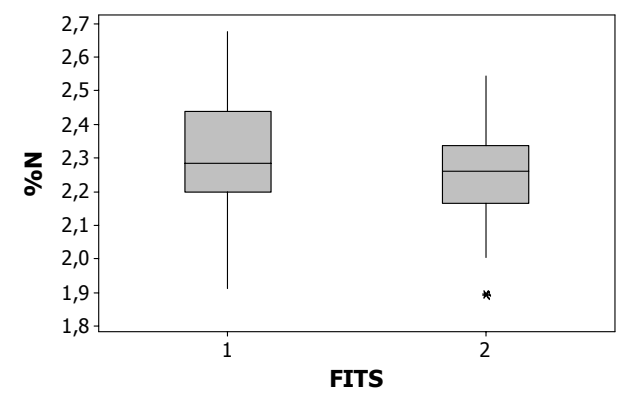

E)

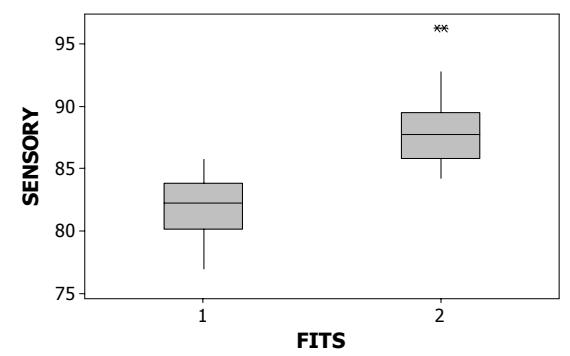

B)

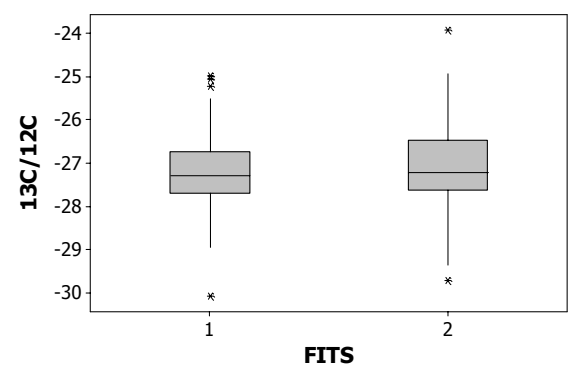

D)

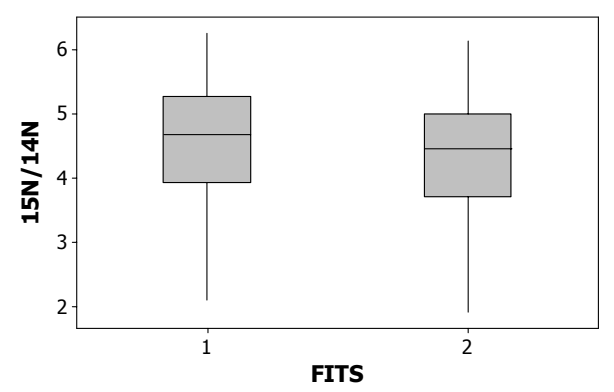

Figure 2. Boxplot of the classification variables $\left(A=C \% ; B=\delta^{13} C ; C=N \% ; D=\delta 15 N\right.$ and $\mathrm{E}=$ final sensory score) of the Processing model grouped by the FITS function. The numbers 1 and 2 correspond to dry (natural) processing and wet (mucilage removed) processing, respectively 
In the literature, there are reports on the effect of processing in relation to coffee quality. It is considered to be one of the most important factors that strongly contributes to forming a specialty coffee (Borém et al., 2008; Joët et al., 2010). According to Bytof et al. (2005), wet processing and dry processing affect the chemical composition of the bean, especially the amino acids, organic acids and carbohydrates, which are of fundamental importance for the final quality of the beverage. Barbosa et al. (2010) studied the spatial distribution of quality for the state of Minas Gerais, Brazil and reported considerable difference among the manner of processing, quality and the effect of the environment. According to the authors, the manner of processing can enhance or harm coffee quality as a result of the production environment. Selmaret al. (2002) reported that dry processing is generally characterized by a more full-bodied coffee while, for most terroirs, wet processing gives greater accent to aroma. In Figure 2-E, a relationship is observed between the manner of processing and quality, with processing 1 (dry or natural processing) obtaining scores ranging from $77 \pm 96$ points, although most of the samples had 80 to 85 points. Processing 2 (wet processing or processing with mucilage removed), for its part, had scores ranging from $79 \pm 92$, and most of the samples had 85 to 90 points. These data are shown in Table 2.

Table 2. Mean values, standard deviation and range of values of $\mathrm{C} \%, \mathrm{~N} \%$ and $\delta^{13} \mathrm{C}$ and $\delta^{15} \mathrm{~N}$ and final sensory analysis score of green coffee beans for the three altitude classes $(<1000 ; 1000$ to $1200 ;>1200 \mathrm{~m})$

\begin{tabular}{|c|c|c|c|c|c|c|}
\hline \multirow{2}{*}{ ALTITUDES } & \multicolumn{3}{|c|}{$\delta^{13} \mathrm{C}-\mathrm{NATURAL}$} & \multicolumn{3}{|c|}{$\delta^{13} \mathrm{C}-$ MUCILAGE REMOVED } \\
\hline & Mean & StanDev & Ranges & Mean & StanDev & Ranges \\
\hline 1000 & -27.08 & 0.67 & -25.8 to -28.2 & -27.83 & 1.11 & -26.41 to -30.05 \\
\hline $1000-1200$ & -27 & 1.02 & -25 to -28.64 & -27 & 0.48 & -26 to -28 \\
\hline 1200 & -27 & 0.66 & -26 to -28 & -27 & 1.10 & -25 to -29 \\
\hline \multirow{2}{*}{ ALTITUDES } & \multicolumn{3}{|c|}{$\% \mathrm{C}-\mathrm{NATURAL}$} & \multicolumn{3}{|c|}{$\% \mathrm{C}-$ MUCILAGE REMOVED } \\
\hline & Mean & StanDev & Ranges & Mean & StanDev & Ranges \\
\hline 1000 & 46.36 & 1.85 & 43 to 48 & 47.31 & 2.01 & 43.80 to 49.64 \\
\hline $1000-1200$ & 45.7 & 1.76 & 43 to 48 & 45.9 & 1.98 & 43 to 48 \\
\hline 1200 & 47 & 1.45 & 44 to 48 & 47.2 & 1.11 & 45 to 48 \\
\hline \multirow{2}{*}{ ALTITUDES } & \multicolumn{3}{|c|}{$\delta^{15} \mathrm{~N}-\mathrm{NATURAL}$} & \multicolumn{3}{|c|}{$\delta^{15} \mathrm{~N}$ - MUCILAGE REMOVED } \\
\hline & Mean & StanDev & Ranges & Mean & StanDev & Ranges \\
\hline 1000 & 4.8 & 0.95 & 4.52 to 6.05 & 4.86 & 0.63 & 3.79 to 5.99 \\
\hline $1000-1200$ & 4.05 & 1.10 & 2.78 to 5.25 & 4.49 & 0.94 & 3.72 to 5.90 \\
\hline 1200 & 3.96 & 0.94 & 2 to 5 & 3.81 & 1.14 & 1.9 to 5 \\
\hline \multirow{2}{*}{ ALTITUDES } & \multicolumn{3}{|c|}{$\% \mathrm{~N}-\mathrm{NATURAL}$} & \multicolumn{3}{|c|}{$\% \mathrm{~N}$ - MUCILAGE REMOVED } \\
\hline & Mean & StanDev & Ranges & Mean & StanDev & Ranges \\
\hline 1000 & 2.36 & 0.09 & 2.2 to 2.5 & 2.31 & 0.13 & 2.18 to 2.52 \\
\hline $1000-1200$ & 2.32 & 0.18 & 2.12 to 2.63 & 2.28 & 0.11 & 2 to 2.39 \\
\hline 1200 & 2.16 & 0.16 & 1.9 to 2.4 & 2.19 & 0.15 & 1.8 to 2.3 \\
\hline \multirow{2}{*}{ ALTITUDES } & \multicolumn{3}{|c|}{ Sensorial - NATURAL } & \multicolumn{3}{|c|}{ Sensorial - MUCILAGE REMOVED } \\
\hline & Mean & StanDev & Ranges & Mean & StanDev & Ranges \\
\hline 1000 & 83.57 & 3.92 & 77 to 92 & 82.43 & 2.70 & 79 to 86 \\
\hline $1000-1200$ & 84.2 & 2.89 & 78 to 88 & 84.5 & 2.57 & 80 to 89 \\
\hline 1200 & 90.6 & 3.4 & 88 to 96 & 89.2 & 2.88 & 88 to 92 \\
\hline
\end{tabular}

However, for the first time, it was possible to show the existence of the relationship between the manner of processing, quality and stable isotope ratio by the proposed model, with an accuracy rate of $60 \%$. Even though diverse authors have related the manner of processing with coffee quality (Bytof et al., 2005; Borém et al., 2008; Joët et al., 2010), greater studies in light of the physiology of the coffee plant are necessary to understand the process of isotope distribution in coffee beans. Taking into consideration that the elemental chemical composition 
is affected by diverse factors, among them photosynthesis, and that the compounds generated are then relocated to different parts of the plant, these metabolic events may assist in interpretation of the results obtained in this study.

\subsection{Model 2}

The model generated by means of the linear response method was able to classify 82 of the 119 samples studied, with an accuracy rate of 68.9. The relations between the classification variables and the FITS are represented in Figure 3.

A)

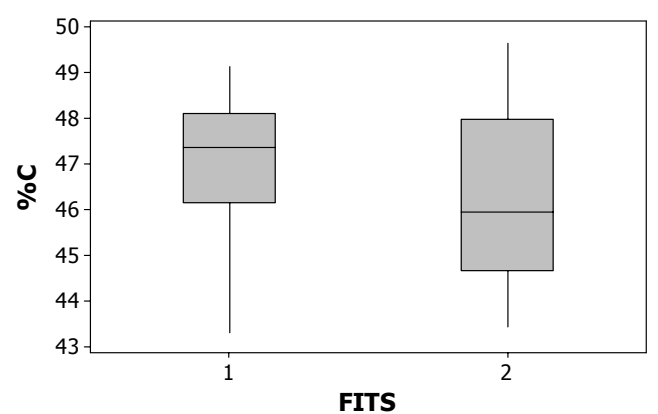

C)

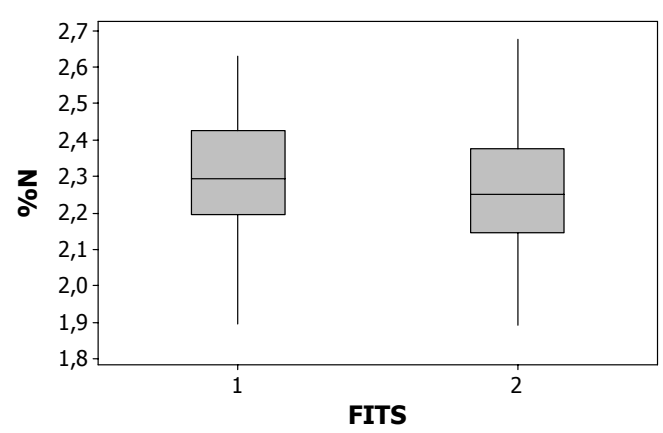

E)

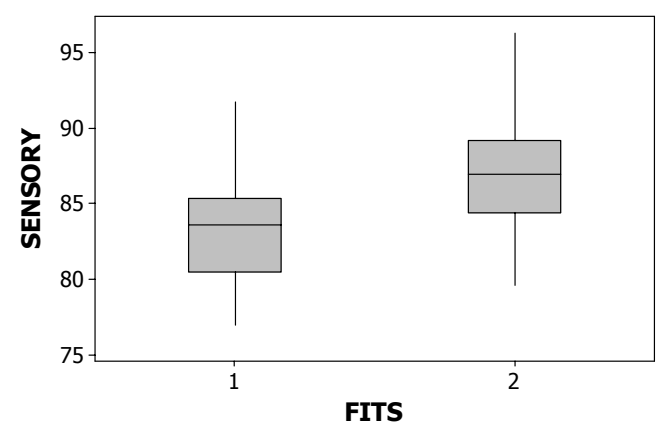

B)

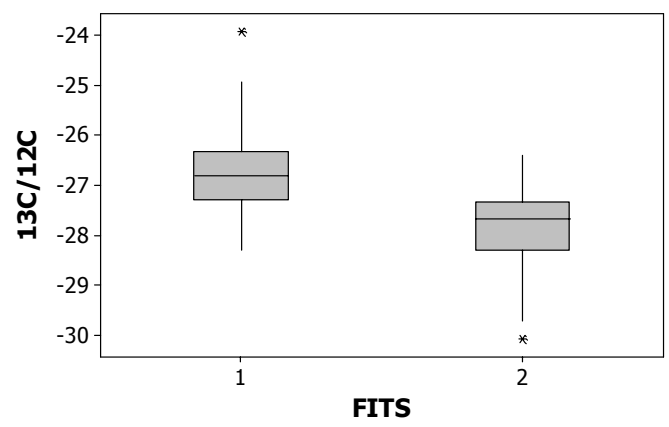

D)

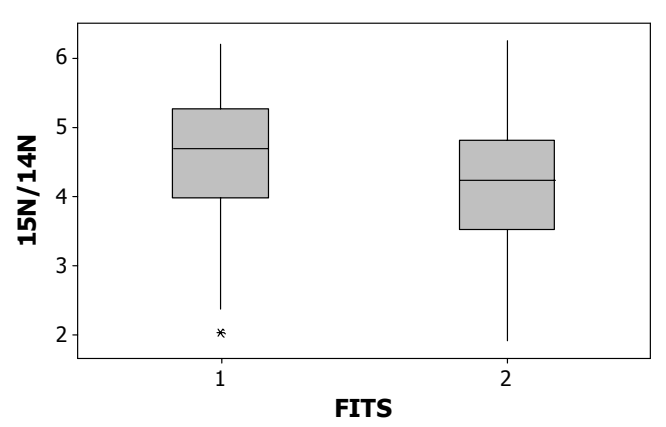

Figure 3. Boxplot of the classification variables $\left(A=C \% ; B=\delta^{13} \mathrm{C} ; \mathrm{C}=\mathrm{N} \% ; \mathrm{D}=\delta 15 \mathrm{~N}\right.$ and $\mathrm{E}=$ final sensory score $)$ of the Color model grouped by the FITS function. The numbers 1 and 2 correspond to the red and yellow colors respectively. This model obtained an accuracy rate of $68.9 \%$ in consonance with linear discriminant analysis

Relations were observed between red fruits and yellow fruits for isotopic abundances and their respective percentages and for sensory analysis. The red color shows greater rates in relation to the yellow color for carbon and nitrogen rates. There was also a trend toward enrichment in the isotope ratio of carbon ${ }^{13} \mathrm{C} /{ }^{12} \mathrm{C}$ and nitrogen ${ }^{15} \mathrm{~N} /{ }^{14} \mathrm{~N}$. Nevertheless, these results indicate that there may be a difference in the form of fractioning these two 
elements due to the variety represented by color. Some authors report that there are some metabolic transformations during maturation of the fruit arising from ethylene synthesis, such as accumulation of sugars, anthocyanins and carotenoids. Carotenoids are responsible for fruit pigmentation (RIBAS et al., 2006). The differences found may be related to the physiological and metabolic performance of each variety represented. Taveira et al. (2011) carried out studies in regard to coffee seed physiology of the varieties Acaiávermelho (red) and Bourbon amarelo (yellow) and observed that Bourbon amarelo had better physiological performance than Acaiá. According to these authors, the results showed the same relation in regard to the beverage - the Bourbon amarelo variety obtained greater sensory scores when compared to Acaiá. Thus, for the first time, it was possible to show the existence of the relationship between color, quality and stable isotope ratio through the proposed model, with an accuracy rate of $68.9 \%$. Nevertheless, new studies are necessary concerning coffee plant metabolism to clarify these events that may later reveal the secrets of such highly appraised specialty coffees.

\subsection{Model 3}

The model generated by means of the linear response method was able to classify 106 of the 119 samples studied, with an accuracy rate of $89 \%$. The relations between the classification variables and the FITS are shown in Figure 4 .

A)

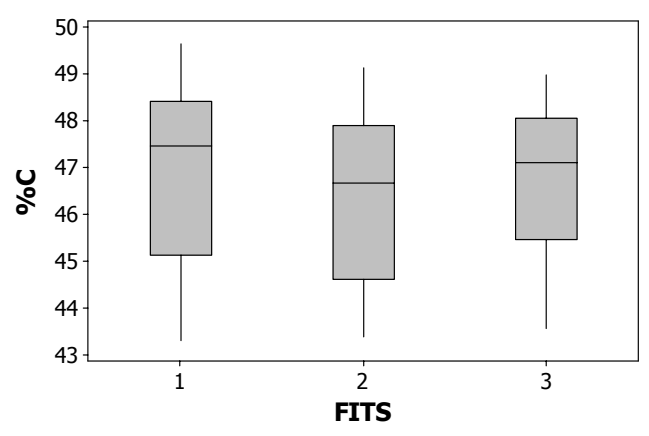

C)

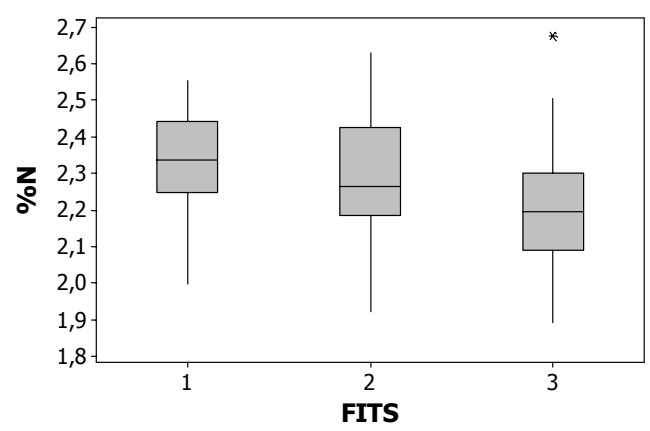

E)

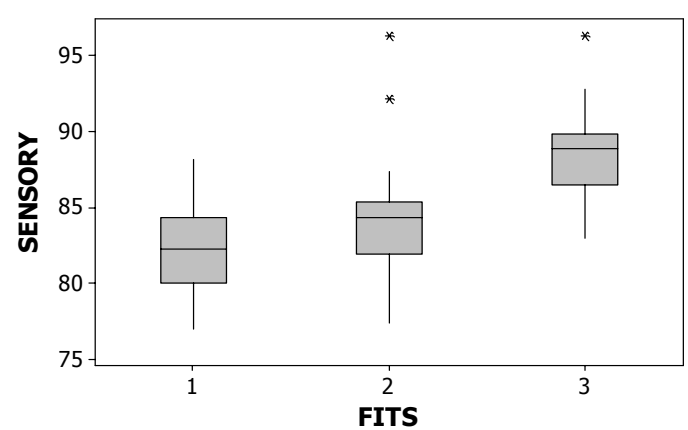

B)

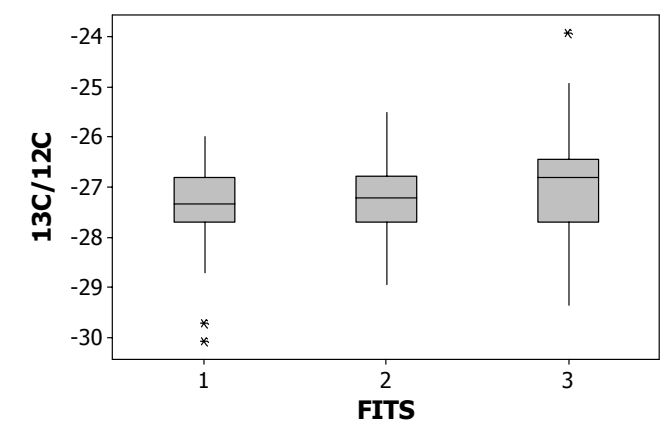

D)

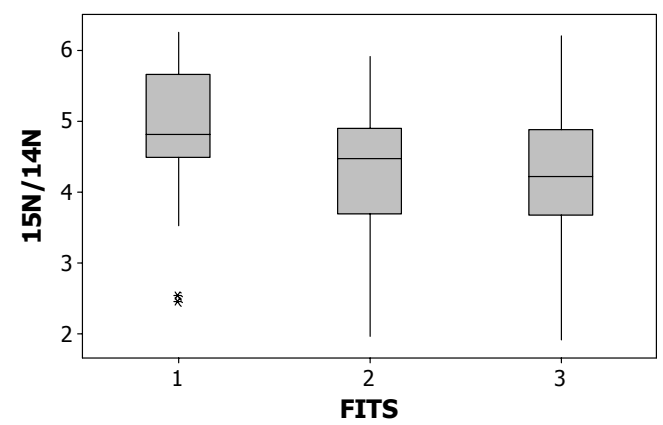

Figure 4. Boxplot of the classification variables $\left(A=C \% ; B=\delta^{13} C ; C=N \% ; D=\delta 15 N\right.$ and $E=$ final sensory score) of the Altitude model grouped by the FITS function. The numbers 1, 2 and 3 correspond to the altitude ranges of below $1000 \mathrm{~m}, 1000-1200 \mathrm{~m}$ and above $1200 \mathrm{~m}$ respectively 
As shown in Table 2, altitudes below $1000 \mathrm{~m}$ had values greater than those found at higher altitudes $\left(\delta^{15} \mathrm{~N}: 4.8 \pm\right.$ $2 \%$ ), a range of roughly $2.8 \%$. That indicates that at higher altitudes, there is a tendency to have lower isotopic abundance of $\delta^{15} \mathrm{~N}$ (Figure 4-D); in other words, the production environment at higher altitudes has a less plentiful isotope ratio of ${ }^{15} \mathrm{~N} /{ }^{14} \mathrm{~N}(3.9 \pm 1.8 \%$ ). Serra et al. (2005) performed studies on nitrogen, carbon and boron isotope ratios by the principal component analysis (PCA) method to discriminate the geographic origin of coffees. The authors obtained bands of $\pm 4.88 \%$ of $\delta^{15} \mathrm{~N}$ (ranging from 6.08 to $1.20 \%$ ). They concluded that the carbon, nitrogen and boron isotope ratios proved to be good indicators of geographic parameters, validating this methodology for use in coffee beans. Gonzalvez et al. (2009) performed studies on marked element composition and stable isotope ratio for food products with Protected Designation of Origin (PDO) and they reported the differences found in ${ }^{15} \mathrm{~N} /{ }^{14} \mathrm{~N}$ and ${ }^{13} \mathrm{C} /{ }^{12} \mathrm{C}$, which are related to agricultural practices. Martinelli et al. (1999) found that rainfall and differences in soil type, among forest types, contribute to variations in nitrogen cycling patterns and, therefore, also to the nitrogen isotope ratio in the plant ${ }^{15} \mathrm{~N} /{ }^{14} \mathrm{~N}$. Such studies are important because they may suggest better interpretation of isotope fractionation of $\delta^{15} \mathrm{~N}$ through the effect of altitude. As shown in Figure 4-E, an increase can be observed in sensory scores with increasing altitude. This effect is opposed to the ${ }^{15} \mathrm{~N} /{ }^{14} \mathrm{~N}$ nitrogen ratio, which shows a trend toward decreasing abundance of the $\delta^{15} \mathrm{~N}$ isotope with increasing altitude (Figure 4-D). Avelino et al. (2005) performed studies on the quality of Costa Rican coffees and observed a positive relation of the effect of altitude on quality. This phenomenon, although not very well understood, was also reported by Barbosa et al. (2012). According to the authors that performed studies on Brazilian coffees, in addition to the quality vs. altitude relation, there is also a relation to latitude arising from rain distribution and temperature. Rodrigues et al. (2009) studied the geographic origin of different coffees in the world by means of the stable isotope methodology in ${ }^{18} \mathrm{O} /{ }^{16} \mathrm{O},{ }^{15} \mathrm{~N} /{ }^{14} \mathrm{~N}$, and ${ }^{13} \mathrm{C} /{ }^{12} \mathrm{C}$ isotopic abundance ratio. Some of the coffees studied by the authors were Brazilian coffees, and the rates they found in regard to $\delta^{15} \mathrm{~N}$ were $0.9 \% \pm \pm 2.8 \%$ or different Brazilian regions. However, Rodrigues et al. (2009), upon reporting values found for $\delta^{15} \mathrm{~N}$ when comparing coffee origins, draws conclusions for a global scale upon comparing different countries and, therefore, quite different values from those shown in this study are presented. Once more, for the first time, the results presented in this study relate isotope ratios with coffee quality and the environment on a limited geographic scale, which showed the effectiveness of the proposed model. The values for different environments in each altitude class from $2.2 \% 0$ to $6.05 \%$, according to some authors, are considered representative for geographic discrimination (SERRA et al., 2005; RODRIGUES et al., 2009; RODRIGUES et al., 2011). The sensory scores obtained showed the excellent quality of the coffee studied, in agreement with the latest results presented by the Cup of Excellence (COE, 2012). Some studies report that the carbon and nitrogen isotope ratios are related to the climatic conditions for plant growth, especially water and nutrient availability, as well as light intensity and temperature. These are fundamental indications for geographic origin (SHIBUYA et al., 2007). Many scientific studies that deal with questions concerning the geographic origin of coffees report that of all the techniques used, stable isotopes have achieved the greatest precision in studies on products of vegetable origin (WECKERLE, et al., 2002; REID et al., 2006; GONZALVEZ et al., 2009; RODRIGUES et al., 2009; RODRIGUES et al., 2011; TECHER et al., 2011). The results presented were able to prove the effectiveness of the methodology used for discrimination of the geographic origin of specialty coffees, showing, for the first time, the relation of quality, environment and isotopic abundance for a limited geographic area when compared to other studies cited in the literature.

\section{Conclusion}

Although this methodology is generally used on a continental geographical scale, this study showed, in an unprecedented way, its applicability on a limited geographic scale.

Since the international market requires excellent standards of quality, placing value on products with country of origin labeling, the need is seen for creation and application of methodologies that add value to fine products such as coffees from the Serra da Mantiqueira of Minas Gerais, thus providing for a positive perception of the coffees produced in Brazil.

\section{References}

Almeida, C. M. E. M., \& Vasconcelos, T. S. D. (2001). ICP-MS determination of strontium isotope ratio in wine in order to be use as a fingerprint of its regional origin. Journal of analytical atomic spectrometry, 16, 607-611.

Avelino, J., Barboza, B., Araya, J. C., Fonseca, C., Avrieux, F., Guyot, B., \& Cilas, C. (2005). Effects of slope exposure, altitude and yield on coffee quality in two altitude terroirs of Costa Rica, Orosi and Santa María de Dota. Journal of the Science of Food and Agriculture, 85, 1869-1876. 
Barbosa, J. N., Borém, F. M., Alves, H. M. R., Volpato, M. L. M., Vieira, T. G. C., Souza, V. C. O. de. (2009). Spatial distribution of coffees from Minas Gerais state and their relation with quality. Coffee Science, 5(3), 237-250.

Barbosa, J. N., Borém, F. M., Cirillo, M. A., Malta, M. R., Alvarenga, A. A., \& Alves, H. M. R. (2012). Coffee quality and its interactions with environment factors in Minas Gerais, Brazil. Journal of agricultural science, 4(5), 181-190, 2012. http:dx.doi.org/10.5539/jas.v4n5p181

Borém, F. M. (2008). Processamento do café. In F. M. BORÉM (Ed.), Pós-Colheita do Café. Lavras: Editora UFLA.

Bytof, G., Knopp, S. E., Schieberle, P., Teutsch, I., \& Selmar, D. (2012). Influence of processing on the generation of $\gamma$-aminobutiric acid in green coffee beans. Eur Food Res Thecnol, 2005. http:dx.doi.org/10.1007/s00217-004-1033-z

Cup of Excellence-Coe. (2012). Relação dos vencedores do ano de 2012. Retrieved from http://www.cupofexcellence.org

GAT, J. R. (1996). Oxygen and Hydrogen isotopes in the hydrologic cycle. Annual review earth planet science, 24, 225-262.

Gonzalvez, A., Armenta, S., \& Guardia, M. de la. (2009). Trace-element composition and stable-isotope ratio for discrimination of foods with protected designation of origin. Trends in analytical chemistry, 28(11), 1295-1311. http://dx.doi.org/10.1016/j.trac.2009.08.001.

Instituto Brasileiro De Geografia E Estatística. Cidades. (2009). Rio de Janeiro, 2009a. Retrieved from ftp://geoftp.ibge.gov.br/MME2007/MG/CARMO\%20DE\%20MINAS.pdf

Joët, T., Laffargue, A., Descroix, F., Doulbeau, S., Bertrand, B., \& Dussert, S. (2010). Influence of environmental factors, wet processing and their interactions on the biochemical composition of green Arabica coffee beans. Food chemistry, 118(3), 693-701. http://dx.doi.org/10.1016/j.foodchem.2009.05.048

Johnson, R. A., \& Wichern, W. D. (2007). Applied Multivariate Statistical Analysis (6th ed.). Pearson.

Lingle, T. R. (2001). The coffee cupper's handbook: systematic guide to the sensory evaluation of coffee's flavor (3 ed.). Long Beach: Specialty Coffee Association of America.

Martinelli, L. A., Ometto, J. P. H. B., Ferraz, E. S., Victoria, R. L., Camargo, P. B. De., \& Moreira, M. Z. (2009). Desvendando questões ambientais com isótopos estáveis. Oficina de Textos. São Paulo.

Martinelli, L. A., Piccolo, M. C., Townsend, A. R., Vitousek, P. M., Cuevas, E., Mcdowell, W., ... Treseder, K. (1999). Nitrogen stable isotopic composition of leaves and soil: Tropical versus temperate forests. Biogeochemistry, 46, 45-65. http://link.springer.com/article/10.1023\%2FA\%3A1006100128782\#page-1

Organizacion Internacional Del Café. (2009). Participação dos mercados e seus coeficientes de ponderação no cálculo dos preços indicativos dos grupos e composto a partir de $1^{o}$ de outubro de 2009. Anexo 1, 2009. Retrieved from http://dev.ico.org/documents/cy2012-13/icc-105-17-a1p-rules-indicator-prices-final.pdf

Reid, L. M., O’Donnell, C. P., \& Downey, G. (2006). Recent technological advances for the determination of food authenticity. Trends Food Science Technology, 17, 344-353. http://dx.doi.org/10.1016/j.tifs.2006.01.006

Ribas, A. F., Pereira, L. F. P., \& Vieira, L. G. E. (2006). Genetic transformation of coffee. Brazilian Journal Plant Physiology, 18(1), 83-94. Retrieved from http:/www.scielo.br/pdf/bjpp/v18n1/a07v18n1.pdf

Rodrigues, C. I., Maia, R., Miranda, M., Ribeirinho, M., Nogueira, J. M. F., \& Maguas, C. (2009). Stable isotope analysis for green coffee bean: A possible method for geographic origin discrimination. Journal of Food Composition and Analysis, 22(5), 463-471, 2009. http://dx.doi.org/10.1016/j.jfca.2008.06.010

Rodrigues, C., Máguas, C., \& Prohaska, T. (2011). Strontium and oxygen isotope fingerprinting of green coffee beans and its potential to proof authenticity of coffee. European Food Research and Technology, 232(2), 361-373. http:dx.doi.org/10.1007/s00217.010.1362-z

Selmar, D., Bytof, G., \& Knopp, S. (2002). New aspects of coffee processing: The relation between seed germination and coffee quality. In Proceedings of the international congress of ASIC. Retrieved from http:/www.docstoc.com/docs/41517426/New-Aspects-of-Coffee-Processing-The-Relation-Between-Seed

Serra, F., Guillou, C. G., Reniero, F., Ballarin, L., Cantagallo, M. I., Wieser, M., .. Vanhaecke, F. (2005). Determination of the geographical origin of green coffee by principal component analysis of carbon, nitrogen 
and boron stable isotope ratios. Rapid communications in mass spectrometry, 19, 2111-2115. http:dx.doi.org/10.1002/rcm.2034

Shibuya, E. K., Sarkis, J. E. S., Negrini-Neto, O., \& Martinelli, L. A. (2007). Carbon and nitrogen stable isotopes as indicative of geographical origin of marijuana samples seized in the city of São Paulo (Brazil). Forensic science international, 167, 8-15. http:dx.doi.org/10.1016/j.forsciint.2006.06.002

Taveira, J. H. D. S., Borém, F. M., Rosa, S. D. V. F. D., Ribeiro, D. E., Chaves, A. R. C. D. S., Ferreira, D. M. D., ... Ribeiro, R. C. (2011). Aspectos Fisiológicos De Grãos De Café Produzidos Em Ambientes Variados Da Micro Região Da Serra Da Mantiqueira.

Techer, I., Lancelot, J., Descroix, F., \& Guyot, B. (2011). About Sr isotopes in coffee "Bourbon Pointu" of the Réunion Island. Food chemistry, 126, 718-724. http://dx.doi.org/10.1016/j.foodchem.2010.11.035

Weckerle, B., Richling, E., Heirinch, S., \& Schreier, P. (2002). Origin assessment of green coffee (Coffea arabica) by multi-element stable isotope analysis of caffeine. Analytical and Bioanalytical Chemistry, 374, 886-890. http:dx.doi.org/10.1007/s00216-002-1560-z

\section{Copyrights}

Copyright for this article is retained by the author(s), with first publication rights granted to the journal.

This is an open-access article distributed under the terms and conditions of the Creative Commons Attribution license (http://creativecommons.org/licenses/by/3.0/). 